\title{
京都議定書・京都メカニズムとわが国の地球温暖化対策 Kyoto Protocol, Kyoto Mechanisms and Japan's Climate Change Policy
}

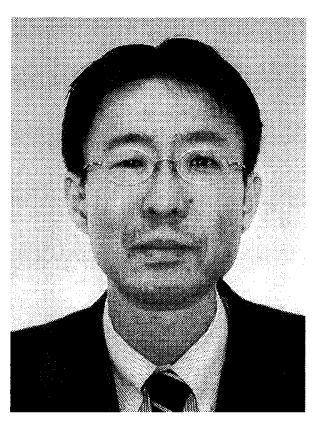

\author{
二宮康司 \\ 環境省 地球環境局地球温暖化対策課 \\ 市場メカニズム室 \\ $\overline{\mathbf{T}} 100-8975$ \\ 東京都千代田区霞ヶ関 1-2-2 合同庁舎 5 号館 \\ Yasushi NINOMIYA \\ Office of Market Mechanisms, Climate Change Policy \\ Division, Global Environment Bureau, Ministry of the \\ Environment, Japan. \\ 1-2-2 Kasumigaseki, Chiyoda-ku, Tokyo, 100-8975,
} JAPAN

論文要旨：京都議定書には, 自国国内からの温室効果ガス排出量の抑制のほかに, 他国から排出枠を購入 することによっても排出削隇目標を達成することができる「京都メカニズム」と呼ばれる仕組みが盛り込ま れている。わが国の温室効果ガス排出量の現状と「京都議定書目標達成計画」を見てみると, わが国の目標 達成はその京都メカニズム活用へ依存していることが明らかとなった。京都議定書は, 将来にわたる長期で の大幅な排出量削減の第一歩として位置付けるべきであり, ポスト京都体制の中でのわが国での一層の温室 効果ガス排出の削減は避けられないと考えられる。このままでは, ポスト京都の枠組みにおいても, 京都メ カニズムに依存した体質が固定化してしまう可能性がある。閉塞状況を打破する温室効果ガス排出削減技術 の開発と普及が渴望される。

\begin{abstract}
Under the Kyoto Protocol, any Annex I country is expected to achieve its commitment target through not only reduction in its domestic GHG emission but also utilisation of the Kyoto Mechanisms. An examination of "The Kyoto Protocol Target Achievement Plan" established by Japanese government implies that Japan's compliance with the protocol would highly depend on the Kyoto Mechanisms. Since the Kyoto Protocol can be seen as the first step towards the long-run emission reduction in the future, it is likely that Japan faces even further GHG emission reduction target in the post-Kyoto regime, where a dependence of "Kyoto Mechanisms", rather than domestic reduction, could be deepened to achieve the target. Avoiding such situation, a development of "break-through" new technologies to reduce GHG emissions is extremely desired.
\end{abstract}

Key words: 気候変動枠組条約, 京都議定書, 京都メカニズム, 京都議定書目標達成計画, 温暖化対 策技術

1 はじめに

近年の地球温暖化問題への関心の高まりから世間で認 知された感のある京都議定書だが，ポピュラーである割 には，その内容については十分には理解されていないよ うである。筆者の勤務先にも数多くの問い合わせが市民 から毎日のように寄せられる。本稿では，はじめに京都 議定書の基本について, とりわけ誤解が多い部分に留意

連絡者：二宮康司

E-mail : YASUSHI_NINOMIYA@env.go.jp
しつつ解説する。中でも京都メカニズムという特徵的な 市場メカニズムを活用した仕組みについてはやや詳細に 説明したい。その上で, 京都議定書で定められた温室効 果ガス排出削減目標を達成するためにわが国ではどのよ うな対策がなされているのか, わが国の推し進める地球 温暖化対策について説明する。その上で, 現在も白熱し た国際交渉が続く，2013 年以降の「ポスト京都」体制 での議論を踏まえながら, 地球温暖化対策としての技術 開発の重要性について述べたい。 


\section{2 気候变動枠組条約（UNFCCC）}

京都議定書は条約ではない。京都議定書は気候変動枠 組条約 (United Nation Framework Convention Climate Change：UNFCCC）という「条約」の究極的な目標 (ultimate object) を達成するために, その条約の枠組 み内で，あらたに合意された法的拘束力を持った国際協 定文書である。ここでの条約の究極的な目標とは，その 第 2 条に「気候システムに対して危険な人為的干涉を 及ぼすこととならない水準において大気中の温室効果ガ スの濃度を安定化させること」と明記されている (UNFCCC，1992)。京都議定書があまりにも有名なた め気候変動枠組条約はつい影が薄くなりがちだが，実は この条約が京都議定書を包含する関係になっており，今 から 13 年前の 1994 年に発効している。

この気候変動枠組条約には京都議定書を離脱した米国 も含めて 2007 年 8 月現在で 192 力国が批准している。 2006 年の段階でわが国政府が承認している国の数は合 計 191 力国であることから，世界中のほぼすべての国が 気候変動枠組条約を批准しているといってよい。これと 比較すると, 2007 年 6 月の段階で京都議定書を批准し ている国の数は 175 力国に留まっている。京都議定書と 比較して気候変動枠組条約が世界各国にこれほど普遍的 に受け入れられている理由の一つが，この条約の「ソフ ト」アプローチである。(Oberhur and Ott, 1999)。それ が故に，「ソフト」アプローチである条約を補完する形 で「ハード」アプローチ，すなわち法的拘束力をもっ た削減義務を先進国に課した京都議定書の策定に結実し たのである。

では気候変動枠組条約には排出削減の具体的目標が まったくないかと言えばそうではなく，先進国からの温 室効果ガスの排出量を 1990 年代の終わりまでに 1990 年 レベルの水準に戻すことが「努力目標」として課せられ ている。なお, 実際には, 先進国全体からの温室効果ガ スの排出量は 1990 年から 2003 年にかけて 6.4\%減少し ているが，これは旧東欧諸国の経済崩壊による $35.5 \%$ の 減少が大きく寄与しており，その一方で，スペイン 40.3\%，ギリシャ $23.2 \%$ ，わが国は 8.3\%など増加してい る国もあり，旧東欧諸国を除くと $0.6 \%$ の増加となって いる。

ここでいう先進国とは, 正確には気候変動枠組条約の 最後に添付されている附属書 I（Annex I）に列挙され た各国を指すことから，しばしば附属書 I 国（Annex I countries）と呼ばれる。これに対して，この附属書 Iに 明記されていない国々は非附属書 I 国と呼ばれ，条約上 では途上国として扱われる。これらの区分はこの条約が
採択された今から 15 年前の 1992 年当時の各国状況を反 映しており，今日では先進国と見なされるべき韓国が途 上国とされている。

これまで繰り返し述べたように京都議定書は気候変動 枠組条約の基本的フレームワークの中に包含されてい る。このため, 数多い京都議定書への批判の多くは, 実 はその上位に位置する気候变動枠組条約の持つ本質的な 問題であることも多い。もっとも頻繁に耳にする議定書 への批判は，「附属書 I 国だけに排出削減義務が課せら れており，中国・インドなど非附属書 I 国は何らの義務 もない」というものである。米国ブッシュ大統領はこの 点を含めて京都議定書には致命的な欠陥がある，として 議定書を離脱した。ところが，こういった附属書 I 国 （先進国）と非附属書 I 国（途上国）の責務に明確な違 いを設けているのも京都議定書を包含する気候変動枠組 条約の基本姿勢であり，決して京都議定書固有の問題点 ではない。

気候変動枠組条約の第 3 条は「締約国は…それぞれ共 通に有しているが差異のある責任および各国の能力に従 い...先進国は率先して気候変動およびその悪影響に対処 すべきである」とした上で, 条約第 4 条において「附属 書 I 国は率先して温室効果ガスの排出抑制に取り組む」 と明記している。要約すれば，「今日の気候変動に対し て世界各国は共通の責任を負っているが，その責任には 先進国と途上国とで差があるので，まず先進国が率先し て排出削減を行う」ということである。これは，「共通 しかし差異のある責任：common but differentiated responsibility」という言葉でしばしば表現され，条約の みならず京都議定書にも一貫して共通する重要な基本原 則として知られる。

\section{3 京都議定書}

その京都議定書は 1997 年, 京都で開催された気候変 動枠組条約第 3 回締約国会合 (Conference of the Party the Third Session：COP3）において採択された。上述 したように, 京都議定書は気候変動枠組条約の究極的目 標を達成するために条約の枠内での合意文書である。そ の特徵は，先進国としての附属書 I 各国に 2008 年から 2012 年までの 5 年間における温室効果ガス排出量の上 限值を法的拘束力のある数值目標として課しているこ と, そして, その目標達成のために（後述する）京都メ カニズムという排出量取引の仕組みを活用できることで ある。

議定書の下での排出規制対象となっている温室効果ガ スは, 二酸化炭素 $\left(\mathrm{CO}_{2}\right)$, メタン, 一酸化二窒素, 代 替フロン等 3 種類のガス（HFC 類, $\mathrm{PFC}$ 類, $\mathrm{SF}_{6}$ ) の 6 
種類である ${ }^{1 *}$ 。この 6 種類の他にも CFC 類, $\mathrm{HCFC}$ 類, ハロン類, 四塩化炭素など温室効果ガスは数多く存在す るが，オゾン層破壊物質としてすでにモントリオール議 定書による規制対象となっているガスを除いた結果，こ の 6 種類に限定された。

京都議定書で規制対象となっているこれらの 6 種類の ガスは，それぞれ一定質量によって一定期間の間に生じ る地球温暖化への寄与の度合いが異なる。このため，温 室効果ガスの排出量を算定する際は，同質量の二酸化炭 素の大気中排出による 100 年間の寄与との比を見積もっ た地球温暖化係数 (Global Warming Potentical : GWP 二酸化炭素 $1 \mathrm{t}=\mathrm{GWP} 1$ とする）による換算を施し，6 種類すべてのガスを二酸化炭素換算 $\mathrm{t}\left(\mathrm{t}-\mathrm{CO}_{2}\right)$ として 数值化することとしている。たとえば，京都議定書での メタンの GWP は 21 とされており，メタン $1 \mathrm{t}$ の排出は $21 \mathrm{t}-\mathrm{CO}_{2}$ の排出として算定し, 逆にメタンを $1 \mathrm{t}$ 削隇し たとすると， $21 \mathrm{t}-\mathrm{CO}_{2}$ 削減したと算定される。化学的に 安定した物質である HFC 類は非常に高い GWP 值を 持っており，たとえば，HFC-23 の GWP は 17,700, $\mathrm{SF}_{6}$ は 22,000であり, 微量の排出によっても極めて強力な温 室効果をもたらすガスとして知られる。

わが国の場合, 6 種類の温室効果ガス排出量総数のう ち，主に化石燃料の燃焼に伴って排出される $\mathrm{CO}_{2}$ が 90\%以上を占める。これは，エネルギー消費を伴う工業 生産活動が，メタンや $\mathrm{N}_{2} \mathrm{O}$ の排出を伴う農業生産活動 を圧倒しているわが国の工業型生産構造を反映してい る。ところが，世界全体を見ると， $\mathrm{CO}_{2}$ 排出量の割合は $60 \%$ にまで低下するため，世界全体では $\mathrm{CO}_{2}$ 以外のガ スの存在も無視はできない。たとえば，国の基幹産業が 酪農であるニュージーランドのように，牛のゲップから 排出される $\mathrm{CH}_{4}$ の割合が国全体の温室効果ガス排出量 の $35 \%$ を占め，二酸化炭素の割合が $45 \%$ にまで低下し ている国も存在する。このような国では，省エネなど化 石燃料の消費抑制と並んで，家畜飼料の改善など酪農対 策も地球温暖化対策の主要なメニューに含まれる。

京都議定書によって 2008 年から 2012 年の 5 年間にお ける排出量の上限值が課せられている附属書 I 国の合計 $\mathrm{CO}_{2}$ 排出量の全世界 $\mathrm{CO}_{2}$ 総排出量に占めるカバー率は 概ね 3 割であり，このカバレッジの狭さが議定書の問題 点としてしばしば指摘されている。これは米国の離脱と 中国が非附属書 I 国となっていることに起因する。京都 議定書の枠組みは 2012 年までしか規定しておらず, 2013 年以降のいわゆる「ポスト京都」の体制について

${ }^{1 *} \mathrm{HFC}$ 類, $\mathrm{PFC}$ 類は自然界には存在しない人為的に生成されるガ スであり，その派生ガスが数多く存在しているが，煩雑になるた め京都議定書ではそれらを類ごとに一括して扱うことが多い。
は現在国際交渉が進められているところだが，世界の 4 割の排出を占めるこの二カ国をどう扱うかが「ポスト京 都」交渉の最大課題であることは言うまでもない。仮に この二カ国が「ポスト京都」の中で何らかの排出目標を 課すことができればカバレッジは $70 \%$ 越え, その実 効性は飛躍的に高まることになる。

ところで，京都議定書の排出量の上限値は基準年排出 量から各国別の排出削減割合という形で議定書の附属書 B に規定されている。わが国の場合は基準年比 $\lceil 94 \% 」$ とされており，つまり基準年排出量から $6 \%$ 減のレベル が排出上限值ということを意味する。この際用いられる 基準年排出量は, 1990 年の $\mathrm{CO}_{2}$, メタン, $\mathrm{N}_{2} \mathrm{O}$ の排出 量に, 1995 年の $\mathrm{HFC}$ 類, $\mathrm{PFC}$ 類, $\mathrm{SF}_{6}$ の排出量を合計 して算出され，わが国の場合は 12 億 6,144 万 $\mathrm{t}-\mathrm{CO}_{2}$ で ある。1990 年の $\mathrm{CO}_{2}$ 排出量（11 億 4,400 万 $\mathrm{t}-\mathrm{CO}_{2}$ ) が 基準年排出量であるとの認識が一般に見受けられるが, これは誤りである。

Fig. 1 は京都議定書の目標達成の可否をどのように評 価するのかをより詳細に図示したものだが，ポイントは 「排出枠」と「排出量」という 2 つの概念を相対化させ ることである。Fig. 1 の中で，左側が排出枠，右側が排 出量を表している。ある附属書 I 国が保有する排出枠の 量（左側のバーの高さ）が，右側に積み上げられた 2008 年から 2012 年の 5 年間におけるその国の温室効果 ガス排出量の高さと同じ，または高ければ，その国は京 都議定書の目標は達成したと見なされる。2008 年から 2012 年までの 5 年間の排出量が国連の審査チームによ る審査を経て確定する 2015 年中頃には，このようにし て京都議定書の目標達成の可否は最終的に決定されるこ とになる。

Fig. 1 の左端にある低いバーが基準年排出量であり， わが国の場合，12 億 6,144 万 $\mathrm{t}-\mathrm{CO}_{2}$ で確定していること はすでに述べた。これを単純に 5 倍すると左から二つ目 のバーになる。（基準年排出量 $\times 5$ ） から 6\%分を差し引 いたもの（すなわち 12 億 6,144 万 $\mathrm{t}-\mathrm{CO}_{2} \times 5$ 年分 $\times$ 0.94），これが京都議定書に基づいて国連からわが国に割 り当てられる「初期割当量」と呼ばれる「排出枠」であ る。それが左から 3 つ目のバーの高さによって表現され ている。

さらに 4 つめのバーは「森林管理による吸収量の確 保」と呼ばれ，国内における適切な森林管理活動（下刈 り，間伐等）によって吸収される $\mathrm{CO}_{2}$ 量を算出して発 行される排出枠である。このタイプの排出枠発行量は国 際合意で各国別に上限值が設定されており，わが国の場 合, 最大で 2 億 3,800 万 $\mathrm{t}-\mathrm{CO}_{2}$ までである。以上の「初 期割当量」と「森林管理による吸収量に基づいて発行さ 


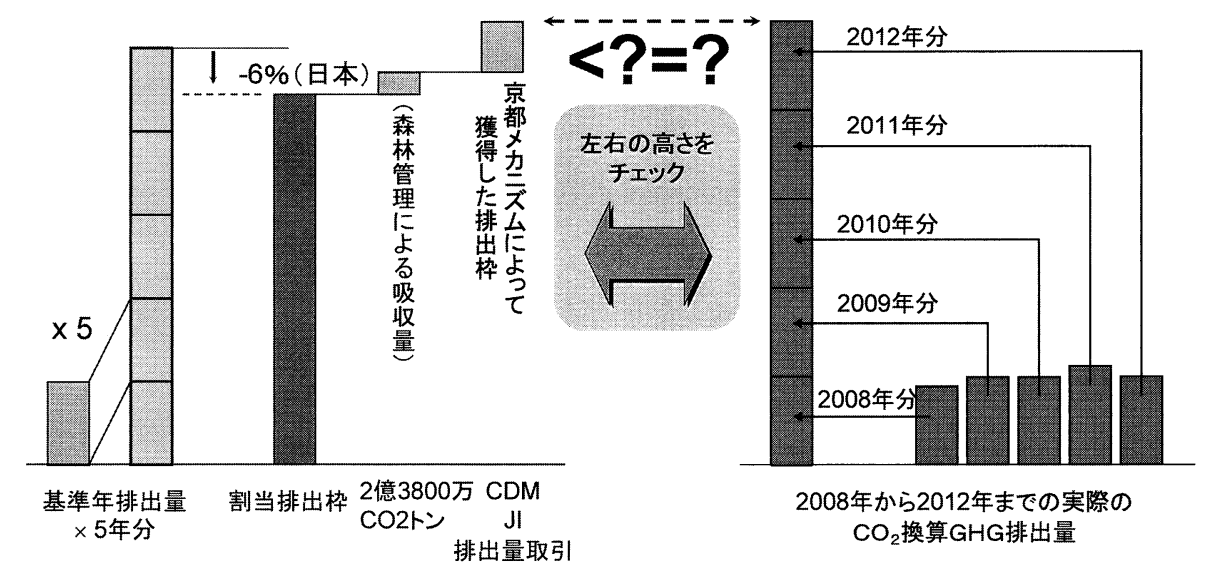

図の出典 : Howard, A. (2001), Modalities for the accounting of assigned amounts under Article 7.4 of the Kyoto Protocol, paper presented in COP7, Marrakech に加筆・修正

Fig. 1 京都議定書目標達成可否の評価

れる排出枠」が附属書 I 各国が自給できる「排出枠」の 最大量となる。わが国の場合， $\left\{\left(12\right.\right.$ 億 6,144 万 $\mathrm{t}-\mathrm{CO}_{2} \times$ $5 \times 0.94)+2$ 億 3,800 万 $\left.\mathrm{t}-\mathrm{CO}_{2}\right\}=$ 合計 61 億 6,700 万 $\mathrm{t}-\mathrm{CO}_{2}$ となる。

以上説明した「排出枠」に相対する概念が，右側の バーの高さで示された「排出量」であり，これは 2008 年から 2012 年までの 5 年間における温室効果ガスの累 積排出量である。ここで, 右側のバーの高さで表された 「排出量」と, 左側のバーの高さで表現された「排出枠」 の量を Fig. 1 の例で比較してみると,「京都メカニズム によって獲得した排出枠」とされている分だけ左側の排 出枠の量が少ない。つまり，「京都メカニズムによって 獲得した排出枠」が不足しているこの状態では, 京都議 定書の目標達成ができなくなってしまうのである。後述 するように，わが国は，京都議定書目標達成のために， この京都メカニズムの活用は必須とされており，この

Fig. 1 で示されたケースがわが国に当てはまる。

京都議定書の不遵守に陥らないようにするために, 政 府は異なった $2 つ の$ 政策を採ることができる。一つは, 京都メカニズムを活用して, 海外から「排出枠」を獲得 してきて，左側のバーに積み上げることにより，保有す る排出枠の量を増加させることである。つまり，これは 「排出枠」増加に関する政策である。

もう一方の政策は，2008 年から 2012 年までの国内か らの温室効果ガスの排出を削滅することにより, 右側の バーの高さを低下させることである。こちらは，「排出 量」削減に関する政策である。「排出枠」増加と「排出 量」削減，この両方の政策を同時に行い，左側の「排出 枠」の量が少なくとも右側の「排出量」と同量になるこ とを確実にすることが京都議定書目標達成のために附属 書 I 各国政府がなすべきこととなる。
京都議定書には, 後者の「排出量」削減が各国がとる 主たる政策であるべきであり，前者の京都メカニズム活 用による「排出枠」増加は，その「排出量」削減に対し て補完的であるべきとする「補完性の原則」が定められ ている。換言すれば，国内での「排出量」削減の努力を 最大限行った上で，それでも「排出枠」量が不足する場 合には，京都メカニズム活用による「排出枠」増加を行 うことができるということである。排出量増加が著し く, 削隇の余地がない場合, 京都メカニズムの活用は議 定書達成のための最後の補足的手段ということになる。

\section{4 京都メカニズム}

京都メカニズムには 3 種類の仕組みがあり，それぞれ 「クリーン開発メカニズム」(Clean Development Mechanism : CDM), 「共同実施」(Joint Implementation : JI），そして「国際排出量取引」として京都議定書に規 定されている。いずれも役割としては，わが国などの附 属書 I 国が，自国からの国内排出量が十分に削減できな い場合に，他国から排出枠を購入してきて自国の排出枠 を積み増しするという点では同じであり，広義の意味で の「排出量取引」である。

3 種類の京都メカニズムのうち, とりわけ CDM の注 目度が高い。なぜなら，3つの京都メカニズムのうち， CDM だけが，附属書 I 国と非附属書 I 国を結びつける 役割を担っており，新しい形態による先進国と途上国と の双方向の環境協力を作り出したからである。他の $2 つ$ （JI と国際排出量取引）が附属書 I 国同士だけのやり取 りであるのとは対象的である。

繰り返しになるが，わが国をはじめとする附属書 I 各 国は 2008 年から 2012 年までの 5 年間に自国内からは温 室効果ガスの排出を約束したレベルまで抑制せねばなら 
ない。しかし，上述したように，気候変動枠組条約に よって合意された「共通しかし差異のある責任原則」に 基づき，非附属書 I 国にはそのような義務的な削減は求 められていない。このため, 経済成長に伴う非附属書 I 国からの温室効果ガスの排出の増加が懸念される。そこ で，急増する途上国からの排出量の「増加率」を抑制す るために考案された仕組みが CDM である。

具体的には, 非附属書 I 国において何らかの温室効果 ガスの排出削減事業を実施した場合に（このような事業 を CDM プロジェクトと呼ぶ)，その事業によって削減 できた温室効果ガスの排出量をモニタリング・算定し, 国連の認定を経た上で, 国際的に取引可能な排出枠とし て発行し, 附属書 I 国がこれを購入し, 京都議定書の目 標達成のために活用することができるという仕組みであ る。

CDM を円滑に実施するためには，附属書 I 国による 排出枠の需要が必要であるが，後述するように，わが国 をはじめとする附属書 I 国による排出枠の高い需要があ り，世界各地の途上国において現在までに約 1,000 件も の CDM プロジェクトが実施されている。その削減技術 の多くは, 風力発電, 水力発電, バイオマス発電, メ夕 ン回収, $\mathrm{HFC}$ 破壞, $\mathrm{N}_{2} \mathrm{O}$ 分解など先進国では一般に普 及しているものである。

途上国での排出削減プロジェクトからの排出枠移転を 行う CDM に対して, JI（共同実施）はある附属書 I 国 において排出削減プロジェクトを実施し, その削減分を 他の附属書 I 国に移転する仕組みである。例としては,
ロシアにおいてわが国が何らかの排出削減事業を実施 し，ロシアに初期配分された排出枠をわが国が譲り受け るケースである。附属書 I 国に初期配分された所与量の 排出枠をやり取りするだけなので，どれだけ大量の排出 枠がJIによってやり取りされたとしても, 世界中の排 出枠の総量に変化はない。

$\mathrm{CDM}$ とはここが異なっており，CDMの場合は，非 附属書 I 国で排出枠が新たに発生するため,この新たに 発生した分は，あらかじめ附属書 I 国に配分されている 排出枠に対して「追加」されることになり，結果として 附属書 I 国全体からの排出量が増加することになる。

これまで説明してきた CDM と JI は共に何らかの排出 削減プロジェクトの実施がその背景にあり，そのプロ ジェクトで削減された排出量を測定・算定し，その量に 対応する排出枠を需要する附属書 I 国へ移転させる仕組 みであった。これに対して, 京都メカニズムの残りの仕 組み，「国際排出量取引」には特定の排出削減プロジェ クトはその背景に必ずしも存在しない。その代わりに， 附属書 I 国から別の附属書 I 国へ「お金」が支払われ， その対価として，排出枠が移転されるものである。した がって，CDM や JI と比較すると仕組みはシンプルであ る。JI と同様に, あらかじめ初期割当てされた所与量の 排出枠が附属書 I 国間でやり取りされるだけなので, 国 際排出量取引がどれだけ活発に行われたところで, 先進 国全体の排出量の上限值に変わりがないことに注意した w。

附属書 I 各国は, 補足性原則の下で，これら CDM，

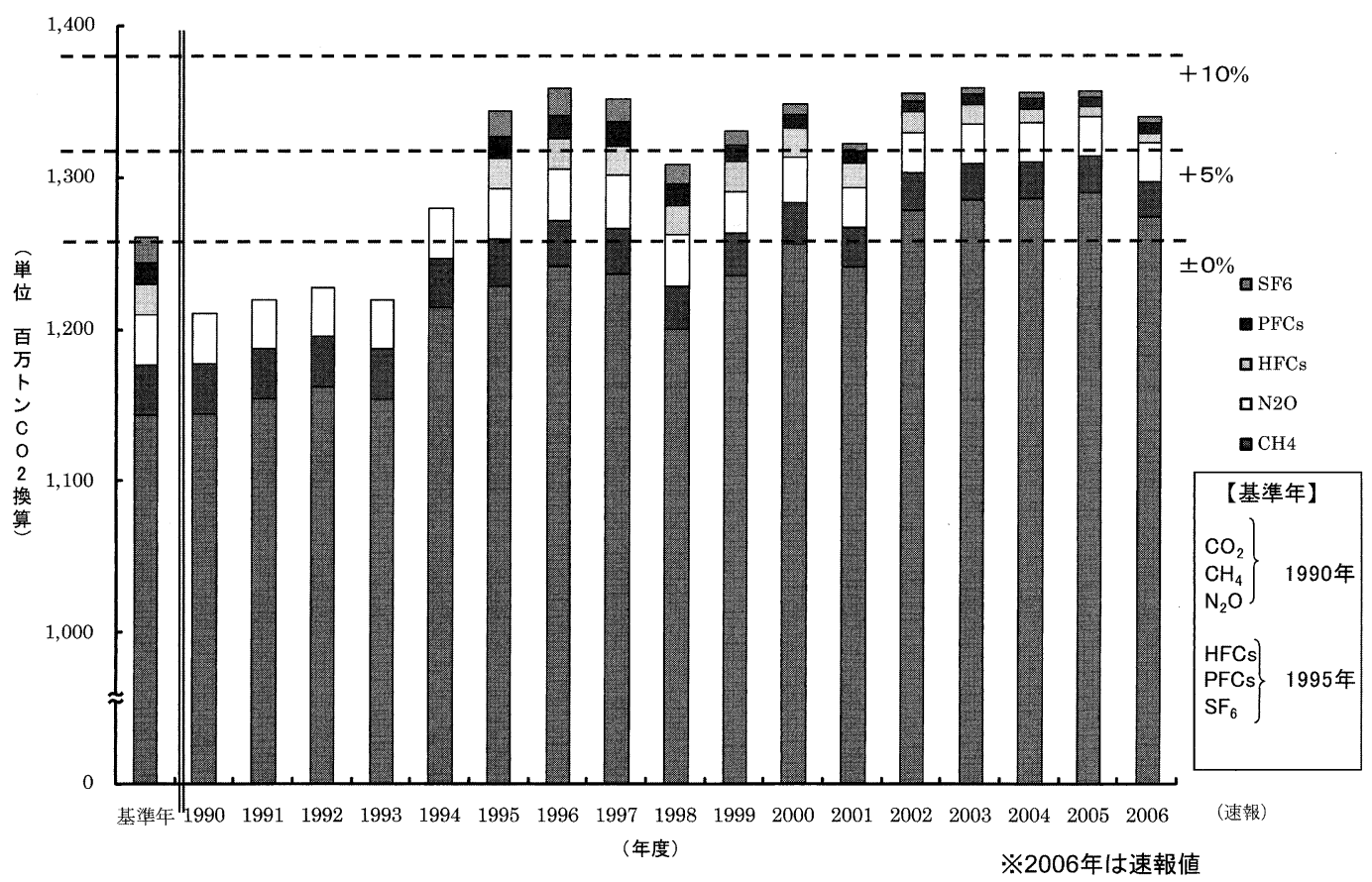

Fig. 2 わが国の温室効果ガス排出量推移（1990-2005 年) 
JI，国際排出量取引のいずれの京都メカニズムを活用し て目標達成してもよいこととなっている。

\section{5 わが国の温室効果ガス排出量}

これまで京都議定書での排出量の目標達成のために， 京都メカニズムの果たす機能を説明してきた。では，肝 心のわが国国内からの排出量を抑制するための排出削減 対策はどうなっているのだろうか。

まずわが国の温室効果ガス排出量の実態を見てみよ う。Fig. 2 はわが国の基準年排出量と 1990 年から 2005 年までのわが国国内からの温室効果ガスの排出量の推移 を表したものであるが，基準年排出量に対して減少する どころか，逆にほぼ増加の一途を迻り，2005 年の排出 量は, 基準年排出量比で 7.8\%の増加という結果となっ ている。いわゆるバブル経済の崩壊後の経済停滞期に相 当するこの時期に, 温室効果ガスの排出量が増加し続け ていたということは興味深い事実である。

実はこの排出量増加の要因はすべて $\mathrm{CO}_{2}$ の排出増加 によるもので，中でも化石燃料の燃焼に伴って排出され る「エネルギー起源 $\mathrm{CO}_{2} 」$ の 2005 年排出量は基準年総 排出量比 $11.2 \%$ 増加となっている。また，プラスチック 類の廃棄物焼却やセメント生産など工業プロセスにおけ る化学反応に伴って排出される「非エネルギー起源 $\mathrm{CO}_{2} 」$ 排出量も同 $0.3 \%$ の増加となっている。

これら $\mathrm{CO}_{2}$ 排出量の増加に対して, 他の 5 種類のガ スについては逆に排出量の減少が顕著である。たとえ ば，メタンの 2005 年排出量は基準年総排出量比で $0.4 \%$ 減, $\mathrm{N}_{2} \mathrm{O}$ は同 $0.5 \%$ 減, $\mathrm{HFC}$ 類, $\mathrm{PFC}$ 類は同 $2.6 \%$ 減と 軒並み減少しており，大幅増加の $\mathrm{CO}_{2}$ 排出量とは極め て対照的な構図となっている。排出源が比較的限定され た $\mathrm{CO}_{2}$ 以外の 5 ガスと比較して，あらゆる社会活動に 伴って排出される $\mathrm{CO}_{2}$ のコントロールがいかに困難か をこの事実は如実に物語っている。

基準年排出量から $6 \%$ の削減が京都議定書の目標であ るのに，2005 年までに逆に $7.8 \%$ 増加したわけだから，
目標達成のために，今後 2008 年から 2012 年の 5 年間に 単純計算で現状から毎年平均 10 数\%程度の削減が必要 になるわけである。これを政策的にどのように実行して ゆくのか，具体的施策を政策決定したものが 2005 年 4 月に閣議決定（2006 年 7 月に一部変更）された「京都 議定書目標達成計画」である（地球温暖化対策推進本 部，2006）。この「京都議定書目標達成計画」こそがわ が国における地球温暖化対策の要であり，この計画にお いて規定された個別の施策を着実に実行してゆくことが 行政の役割となっている。

Table 1 は,「京都議定書目標達成計画」に示されてい る $6 \%$ 目標達成のためのさまざまな施策を取りまとめ て, 分野別にどの程度まで削減するのかの個別目標をそ れぞれ基準年排出量に対するパーセンテージで示したも のである。たとえば，エネルギー起源 $\mathrm{CO}_{2}$ の場合 +0.6 となっているのは，2008 年から 2012 年までの 5 年間に おけるエネルギー起源 $\mathrm{CO}_{2}$ 排出量の平均值を, 基準年 総排出量（12 億 6,100 万 $\mathrm{t}-\mathrm{CO}_{2}$ ) と比較して $0.6 \%$ 増の レベルまでに増加を抑制することが「目標達成計画」を 実行した結果の政策目標という意味である。

この目標達成計画とわが国の現実の排出量を比較する と, 2005 年のエネルギー起源 $\mathrm{CO}_{2}$ 排出量は基準年比 $11.2 \%$ レ゙ルまで増加しているので, 今後, $10.8 \%$ 分の 排出削減を実施することを意味する。一方, $\mathrm{CO}_{2}$ 以外の 5 ガス（メタン, $\mathrm{N}_{2} \mathrm{O}$, 代替フロン等 3 ガス（HFC, $\left.\left.\mathrm{PFC}, \mathrm{SF}_{6}\right)\right)$ は, 目標達成計画での目標值をすでに超過 達成しており, 計画通り順調に進渉している。つまり, 議定書の目標達成可否はもっぱら $\mathrm{CO}_{2}$ 排出量をいかに 削減できるかという点にかかっている。

Table 1 に列挙された分野別の削減目標を合算すると 京都議定書の目標である基準年総排出量比 $-6 \%$ となる ことが確認できる。この中で，京都メカニズムにより排 出枠を積み増す $1.6 \%$ 分, そして森林経営等による吸収 量の確保による排出枠 $3.9 \%$ 分は，すでに説明したよう に，わが国の「排出枠」の積み増しである。繰り返す

Table 1 京都議定書目標達成計画の分野別の削減目標

（基準年総排出量比）

\begin{tabular}{|c|c|c|c|}
\hline \multicolumn{3}{|l|}{ 区 } & 目 \\
\hline (1) エネルギー起源の二酸化炭素 & $\begin{array}{l}\text { 産業部門 } \\
\text { 民生部門 } \\
\text { 運輸部門 }\end{array}$ & $\begin{array}{l}\text { 基準年比- } 8.6 \% \\
\text { 基準年比 }+10.8 \% \\
\text { 基準年比 }+15.1 \%\end{array}$ & $+0.6 \%$ \\
\hline \multicolumn{3}{|c|}{ (2) 非エネルギー起源の二酸化炭素, メタン, 一酸化二窒素 } & $\boldsymbol{\Delta} 1.2 \%$ \\
\hline \multicolumn{3}{|l|}{ (3) 代替フロン等 3 ガス } & $+0.1 \%$ \\
\hline \multicolumn{3}{|l|}{ (4) 森林経営等による吸収量の確保 } & $\boldsymbol{\Delta} 3.9 \%$ \\
\hline \multicolumn{3}{|l|}{ (5) 京都メカニズムの活用 } & $\Delta 1.6 \%$ \\
\hline
\end{tabular}


Table 2 地球温暖化対策の基本構造とわが国の地球温暖化対策

\begin{tabular}{|c|c|c|}
\hline $\begin{array}{l}\text { 地球温暖化をもたらす各要因へ } \\
\text { の対策タイプ }\end{array}$ & パラメータ & $\begin{array}{l}\text { 「京都議定書目標達成計画」（2005 年 } 4 \text { 月閣議決定）に } \\
\text { 盛り达まれている対策（主なものの抜粋） }\end{array}$ \\
\hline 人間・社会の欲望抑制 & $\begin{array}{l}V(\text { サービスに対する人間の価値 } \\
\text { 観) }\end{array}$ & $\begin{array}{l}\text { · 大量生産・大量消費・大量廃棄型の社会経済活動や生活 } \\
\text { 样式の变 } \\
\text { ·不要不急の自動車利用の自肃庵の依存を抑制 }\end{array}$ \\
\hline 脱物質化・節約型社会への変革 & $\begin{array}{l}P \text { (物的生産量 }) / \\
V(\text { サービスに対する人間の価值 } \\
\quad \text { 観 })\end{array}$ & 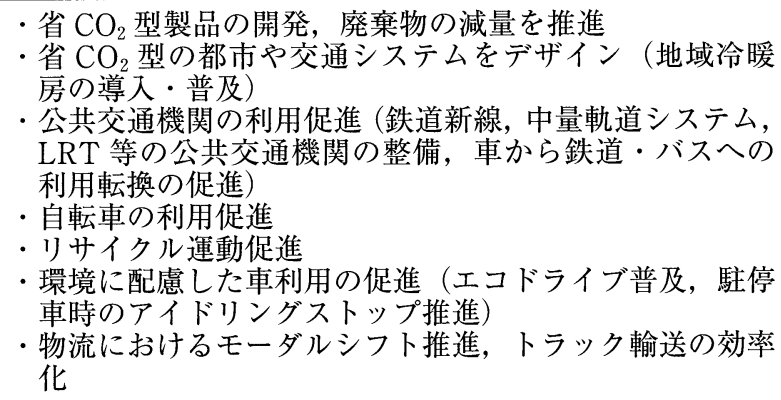 \\
\hline $\begin{array}{l}\text { 単位物的生産量当たりのエネル } \\
\text { ギー効率改善 }\end{array}$ & $\begin{array}{l}E \text { (エネルギー所要量 }) / \\
P \text { (物的生産量 })\end{array}$ & 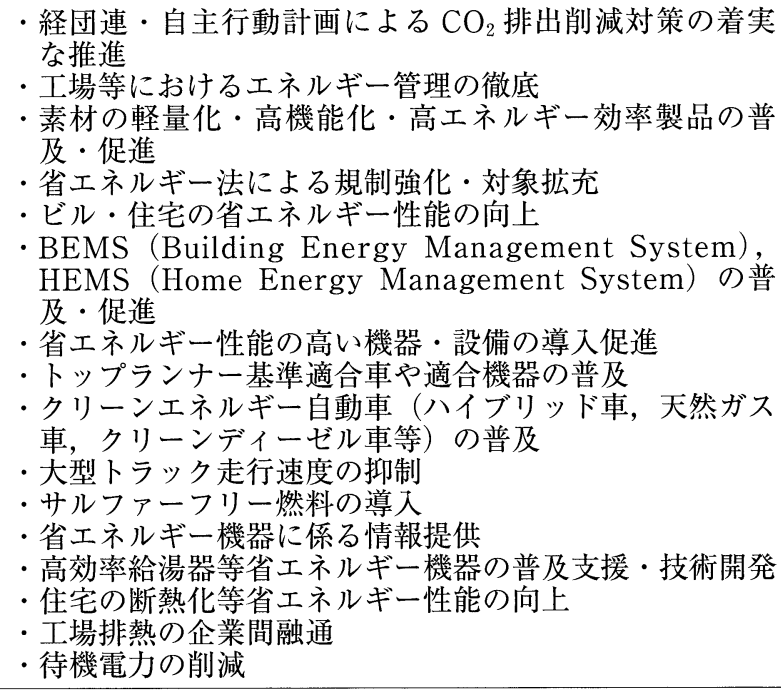 \\
\hline エネルギーシステムの脱炭素化 & $\begin{array}{l}G \text { (温室効果ガス排出量) } / \\
E \text { (エネル゙ー所要量 })\end{array}$ & 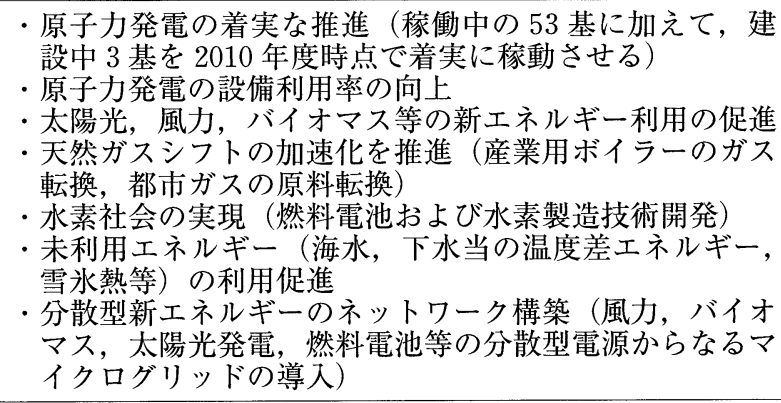 \\
\hline $\begin{array}{l}\text { 大気中の（或いは排出されるで } \\
\text { あろう） } \mathrm{CO}_{2} \text { の除去 }\end{array}$ & $\begin{array}{l}C \text { (大気中の温室効果ガス濃度)/ } \\
G \text { (温室効果ガス排出量) }\end{array}$ & $\begin{array}{l}\text { ·健全な森林の整備,保安林の適切な管理・保安等の推進, } \\
\text { 国民参加の森林づくり等緑化運動の推進 } \\
\text { ·都市緑化等の推進 }\end{array}$ \\
\hline 人間による気候の制御 & $\begin{array}{l}I \text { (地球温暖化へのインパクト)/ } \\
C \text { (大気中の温室効果ガス濃度) }\end{array}$ & （該当なし） \\
\hline 地球温暖化に対する社会の適応 & $\begin{array}{l}D \text { (地球温暖化による損害) / } \\
I \text { (地球温暖化へのインハクト) }\end{array}$ & （該当なし） \\
\hline
\end{tabular}

出典：山地 (2006), 地球温暖化対策推進本部 (2006)

が，森林経営等による吸収量の確保による排出枠 $3.9 \%$ 分は国際合意によってこれ以上カウントすることはでき ない。

議定書目標達成計画において $\mathrm{CO}_{2}$ 排出量の大幅な削
減が計画されている中，もし万が一それが困難となった 場合に，京都メカニズムによる排出枠の購入が目標達成 のための最後の手段として存在していることに注目して おきたい。言い換えれば，国内での $\mathrm{CO}_{2}$ 排出削減が困 
難な場合，もっとも安易な選択肢としての京都メカニズ ムへの依存という構造がわが国に定着してしまう潜在的 可能性があるのである。この場合，わが国国内で排出削 減しない分, 削減対策への資金が海外に流出してゆくこ とになる。

このことを踏まえた上で, $\mathrm{CO}_{2}$ 排出削減のために, 目 標達成計画では，どのような政策を実施してゆくことに なるのかを見てゆこう。

\section{6 わが国の「京都議定書目標達成計画」における $\mathrm{CO}_{2}$ 排出量削減対策}

$\mathrm{CO}_{2}$ 排出の大部分を占める化石燃料使用に伴う $\mathrm{CO}_{2}$ 排出は, エネルギー使用への派生需要によってもたらさ れる。つまり, $\mathrm{CO}_{2}$ 排出そのものは直接的な目的ではな く，エネルギー使用に伴うサービスの享受に伴って派生 的に排出されてしまうものである。人間がサービスを享 受したいという欲求を発するところが問題発生の根源で あり，それが化石燃料の燃焼を伴い，最終的に地球温暖 化をもたらすという諸段階を経るが，その段階毎に温暖 化対策のタイプを分類することができる（山地，2006）。

Table 2 は, わが国の「京都議定書目標達成計画」に 盛り込まれた対策の各メニューをその段階毎にまとめて みたものである。ここに示したように，目標達成計画に 盛り込まれた内容は, 人間・社会の欲望抑制, 脱物質 化・節約型社会への変革, 省エネルギー対策, エネル ギーシステムの脱炭素化, それと森林整備による $\mathrm{CO}_{2}$ 吸収と非常に多岐にわたっている。Table 2 に沿ってそ れらを順に見てゆこう。

まず，人間・社会の欲望抑制だが，もともとこの欲望 が発生しなければ温室効果ガスの人為的排出も生じない
し, 地球温暖化も引き起こされないという根源的な部分 のコントロールである。しかし，これは社会を構成する 個人の価值観に依存する問題であり, 独裁国家でない限 り政策的なコントロールには限界がある。社会の構成員 の価值観の変化あるいはパラダイムシフトは長期的変遷 の中で自然発生的に生じるものであり，短期的な対策と して大きく依存することができない部分である。同様 に, 脱温暖化 ・節約型社会への変革も長期的な視野が必 要な政策であり, 短期間での目標達成への貢献は容易で はない。もちろん, 長期的な社会構造や生活様式の変革 は重要な政策課題だが, 京都議定書の目標期間である 2012 年までの残された 5 年間での対策は，ここで示さ れているように国民への啓発型に限定されてしまいがち だ。その中でも，比較的実行可能と想定されるのは公共 交通機関へのモーダルシフトを中心とする対策であろ う。

わが国は世界に冠たる省エネ先進国として知られる が，その面目躍如たる単位物的生産量当たりのエネル ギー効率の改善は, 目標達成計画の数多い対策メニュー の中心的位置を占め, 具体性が高い部分であり, その進 渉はとりわけ期待されているところである。しかし，エ ネルギー効率改善は一般に年数\%という改善率が出れば 良好な方であり，またエネルギー改善をもたらす新規設 備導入を機動的に行うには障壁も多く，短期間で劇的な 排出削減効果までは容易に結びつけられない。また，生 産活動など活動レベル自体が上昇することによってエネ ルギー効率の効果が絶対排出量では相殺されてしまうこ とも多い。したがって，この部分も着実な進展の確保は 当然のこととしても，省エネルギーによって，今後 5 年 間で $10 \%$ 近い大幅な排出削減効果を得るのは決して容

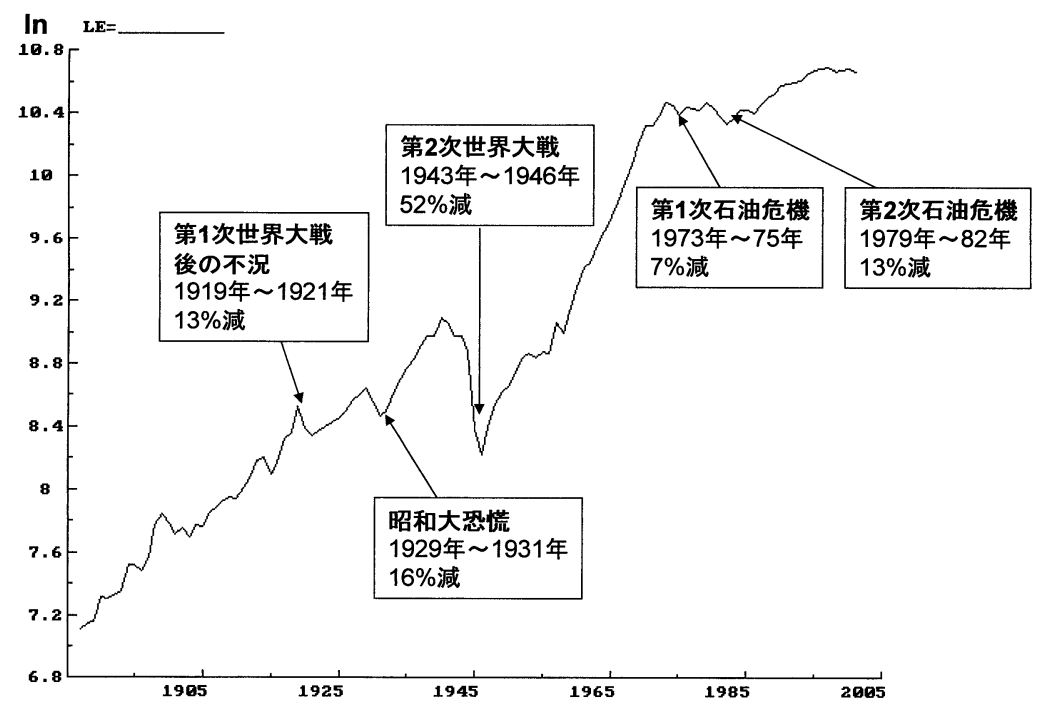

Fig. 3 わが国における一人当たりエネルギー消費量の推移（1887～2004 年） 
易なことではないと考えられる。このことを歴史的に見 てみよう。

Fig. 3 は 1887 年から 2004 年までの過去 117 年間のわ が国に打ける一人当たりのエネルギー消費量の推移をプ ロットしたものである。 5 年間という期間に 10 数\%の エネルギー消費量を削減するという政策目標の要求レべ ルをここで示された過去 117 年間のエネルギー消費量の 推移から見ると次のことが言える。すなわち，1900 年 以降今日に至るまで， 5 年以内の短期間でのエネルギー 消費量の 10 数\%レベルの減少は第 1 次世界大戦, 昭和 大恐慌，第 2 次世界大戦，そして，第 1 次石油危機，第 2 次石油危機の 5 回しか観測されていない。5 回ともそ の主因は外的なショックであり，非常に大きな影響をわ が国の社会・経済・政治に与えた出来事であった。これ らの出来事と同じレベルのエネルギー消費量の大幅な減 少を政策的に実施してゆくことが必要とされているので あり, その困難さは想像に難くない。わが国の技術を もってしても, エネルギー効率改善による短期間での排 出削減の実施となるとその実現は決して容易でないと言 えるだろう。

再びTable 2 に戻るが，続くエネルギーシステムの脱 炭素化は, 最終エネルギー需要に対する $\mathrm{CO}_{2}$ 排出量で あり, 主に発電部門への一次エネルギー投入の構成を低 炭素のエネルギーヘシフトさせてゆくことを目指す。

この部分の最重要課題は原子力発電の着実な推進とさ れて抢り，この計画に盛り込まれた数多い対策メニュー の中での単体での排出削減効果としては最大級の年間 1,700 万 $\mathrm{t}-\mathrm{CO}_{2}$ である。原子力発電を巡ってはその推進 是非をめぐって国内外で議論がなされているところであ るが， $\mathrm{CO}_{2}$ 排出削減に限定して言えば，確実な排出削減 メニューとなる。このため, 目標達成計画では新規稼動 や原子力設備利用率の向上などによる削減効果を十分に 見込んでいるのだが, 新潟県沖地震による柏崎原発の停 止影響などを含めて昨今の諸情勢は厳しさを増してい る。

原子力以外にもこの部門での対策として，太陽光，風 力, バイオマス等の新エネルギー利用の促進も重要な手 段であり，これら新エネルギー対策の推進によって原子 力を上回る年間 4,690 万 $\mathrm{t}-\mathrm{CO}_{2}$ の排出削減を見达んでい る。しかし，その広範な普及にもさまざまな障壁が存在 するため, 2005 年時点での進渉状況は $58 \%$ に留まって おり, これらも問題解決の決定打となり得ていない（地 球温暖化対策推進本部, 2005)。

この部門におけるもう一つの主要な削減対策として, 天然ガスシフトの加速化がある。既存の重油・石炭用燃 焼施設を天然ガス用にエネルギー転換することで数十\%
の $\mathrm{CO}_{2}$ 削減効果が得られるため, 極めて現実的な $\mathrm{CO}_{2}$ 削減手段として期待できる。実際に英国・ドイツなど欧 州諸国で 1990 年代に大幅な $\mathrm{CO}_{2}$ 削減を実施できたの は，既存の石炭火力発電を天然ガス発電へ転換したこと が非常に大きく寄与している。しかし，欧州に扔いては これほど大規模に天然がスへの転換が実施できた理由の 一つは，天然ガスが自国内あるいは近隣諸国からパイプ ラインで供給可能なエネルギーであったからである。 翻って，天然ガスの多くを液化天然ガス（LNG）として タンカーによる輸入に依存するわが国には，その輸入量 に自ずと限界があり，大陸からのパイプライン敷設など 長期的な視野でのインフラ整備が行われないことには欧 州のような全面的な転換は困難であると見られる。天然 ガスシフトで留意しなければならないことは，石炭や重 油との比較に扔いて発熱量当たりの炭素含有量が少ない という天然ガスの優位性も，パイプラインからのガス漏 洩による主成分のメタン（前述したようにその GWP は $\mathrm{CO}_{2}$ の 21 倍である）が大気中に放出されることで相殺 されてしまう可能性があることである。また，LNGの タンカー輸送に際しては少なから媓の LNG が気化し 放出されているとの指摘もあり，少なくとも，わが国の 現状のインフラを前提とすると，化石燃料の全面的な天 然ガスへのシフトが問題解決の決定打とはなり得ないと 考えるべきだろう。

いまひとつの期待される技術である水素社会の実現に ついては，現状では燃料電池技術が実用段階に至ってい るとは言えず，京都議定書の目標達成への寄与度は不確 定である。

最後に，大気中へ排出される $\mathrm{CO}_{2}$ の除去であるが， 現行の対策に盛り込まれているのは森林管理と緑化によ る $\mathrm{CO}_{2}$ の吸収活動である。上述したように，わが国国 内での森林管理による $\mathrm{CO}_{2}$ 吸収量として京都議定書第 1 約束期間の 5 年間に算入可能なのは最大で 2 億 3,800 万 $\mathrm{t}-\mathrm{CO}_{2}$ までと決められており, この最大吸収量の確保を 目指した森林整備が進められている。

この分野の最重要技術として最近にわかに注目を集め つつあるのが，発電所，製鉄所など大規模化石燃焼施設 からの排ガスから $\mathrm{CO}_{2}$ を分離・回収し，その $\mathrm{CO}_{2}$ を地 下帯水層・廃油井等へ貯留してしまう炭素隔離貯蔵 (Carbon Capture and Storage：CCS) 技術である。現 状ではまだわが国の地球温暖化対策メニューの中には盛 り达まれていないが，この技術による潜在的な $\mathrm{CO}_{2}$ の 回収・貯留可能量は全世界で 2 兆 $\mathrm{t}-\mathrm{CO}_{2}$ と推定されてお り（IPCC，2005），世界中の $\mathrm{CO}_{2}$ 排出量（年間 230 億 $\left.\mathrm{t}-\mathrm{CO}_{2}\right)$ の約 90 年分に相当する巨大な量となる。わが国 国内単独でも $\mathrm{CCS}$ 技術によって約 50 億 $\mathrm{t}-\mathrm{CO}_{2}$ の確実性 
の高い貯留ポテンシャルがあると推定されており（地球 環境産業技術研究機構, 2006), わが国の現在の年間 $\mathrm{CO}_{2}$ 排出量 13 億 $\mathrm{t}-\mathrm{CO}_{2}$ と比較しても, その効果は絶大 である。

ただし，この技術にもいくつかの重要な問題点が指摘 されている。一つは $\mathrm{CO}_{2}$ の分離に追加的なエネルギー 投入を必要とすることである。たとえば，CCS 技術を付 した発電は, 同規模の CCS 無しの発電と比較して, 発 電に要するエネルギー投入量が概ね 10～40\%増加する とされている（IPCC，2005 年）。大気中への $\mathrm{CO}_{2}$ 排出 を削減する代償として，より多くのエネルギーが消費さ れてしまうというのは，化石燃料の枯渴性等を考慮する と深刻なジレンマである。また, 適切な条件下では可能 性は低いとされているものの一旦貯留された $\mathrm{CO}_{2}$ が数 百年のオーダーで漏洩することはないのか, 長期での管 理責任やモニタリングはどうするのか, 万が一漏洩した 場合の環境への影響はどうなのか, といった疑問や指摘 がNGO や一部途上国から上がっているのもまた事実で あり，広範なコンセンサスを得るには至っていない。い ずれにせよ，CCS については将来期待される主要技術に は違いないものの, 現状では解決すべき課題も数多く 残っており，現行の京都議定書の削減手法にはなり得て いない。

このように「京都議定書目標達成計画」に揭げられた さまざまな対策メニューを見てみると,「決定打」とな る効果的な排出削減対策がほとんど存在しないことが分 かる。もちろん, 政府としては京都議定書目標達成に向 けて，それぞれの対策を所管の府省を通じて全力で講じ てゆく。しかし，これまでの見てきたことを踏まえる と，現状の対策メニューは決定打に欠け，不確実性が高 い部分も見受けられることから，最終的には京都メカニ ズムへの依存体質となってしまう可能性が強く懸念され る。

\section{7 おわりに}

これまで, 気候変動枠組条約, 京都議定書, 京都メ力 ニズムの仕組み，そして，わが国の「京都議定書目標達 成計画」を見てきた。そして，わが国の京都議定書目標 達成可否が京都メカニズムの活用に依存していることが 明らかとなった。

問題は，この「京都議定書目標達成計画」が着実に進 捗し，京都議定書の第 1 約束期間の目標が達成されたと しても，それは将来にわたる長期での大幅な排出削減の 第一歩に過ぎず，こののちも新たな削減目標が合意さ れ，わが国を含む先進各国は，それに向けて削減対策を 打ち続けなければならないことである。
折しも, 福田総理は先のダボス会議（スイス）で，京 都議定書の次の枠組み, すなわち「ポスト京都」体制に おいて，京都に続く温室効果ガスの新たな国別排出総量 の目標をわが国として揭げることを表明したところであ る（首相官邸，2008）。EU 諸国もすでに 2020 年におけ る 1990 年比 $20 \sim 30 \%$ の削減目標を自主的に掲げている こともあって, ポスト京都の中で京都議定書に代わる新 たな排出削減目標が国際的に合意される可能性が高く なっている。そして，仮にそうなった場合，その排出削 減目標は，2050 年に世界の温室効果ガス排出量を半減 させるという先のハイリゲンダム・サミットにおいて概 ね合意された長期目標を念頭に置いたものである以上， 現状の京都議定書の削減目標から,さらに深堀りしたも のになることは, 先進各国にとって避けられないとみる べきである。このため, わが国としても，京都議定書の 目標達成はもちろんのこと，ポスト京都を見据えた長期 的な排出削減対策のあり方を戦略的に練ってゆく必要が ある。

ところが，先に述べたように，わが国は，少なくとも 京都議定書第 1 約束期間に限ってみても, 京都メカニズ ムへ依存しやすい体質になりつつある。このまま状況が 変化しなければ，一層深堀りした排出削減が要求される であろうポスト京都の枠組みにおいては，京都メカニズ ム（に類似した仕組み）に依存した体質，すなわち，わ が国の資金が海外へ流出してゆく体質が固定化してしま うのではないだろうか。

そこで，わが国の閉塞状況を打破する決定打としての ブレークスルーとなる技術の開発が渴望されるのであ る。換言すれば，「排出枠」を増やす政策（京都メカニ ズム活用）よりも，「排出量」の削減が実行できるよう な劇的な排出削減技術の開発と普及である。もちろん, 京都メカニズムには自国の目標達成のためという側面以 外にも，途上国での排出削減とそれに伴う持続可能な開 発の促進という重要な面があることを忘れてはならない が, 現状の京都メカニズムの位置づけは目標達成のため の最終手段という面が非常に強く強調されている。

技術開発と普及には時間を要する。現状をブレークス ルーする技術開発が一朝一夕で成せるはずがない。とこ ろが，京都議定書第 1 約束期間の削減目標達成期限まで 残り 5 年を切ってしまった現状では，技術開発が大幅な 排出削減につながるにはもはや時間がなくなってきてい る。結局, 京都メカニズムによる排出枠の購入という パッシブな取り組みに依存せざる得なくなってしまうの はこれまで見てきたとおりである。わが国としてこのよ うな事態をポスト京都の次期枠組みにおいて繰り返して はならない。長期の排出削減目標を見据えた技術開発に 
取り組み，国内での排出を削減することによって，「脱 温暖化社会」実現のリーダーシップを発揮し，地球温暖 化に対する先進国としての責任をわが国が果たしてゆく べきではなかろうか。

\section{文献}

1) IPCC, Special Report: Carbon Dioxide Capture and Storage, Inter governmental Panel on Climate Change (2005).

2) S. Oberthur and E.T. Ott, The Kyoto Protocol, SpringerVerlag Berlin Heidelberg (1999), 邦訳 ·京都議定書 : 21 世紀の国際気候政策，岩間徹，磯崎博司監訳，シュプ
リンガー・フェアラーク東京 (2001).

3）首相官邸，ダボス会議における福田内閣総理大臣特別 講演 (2008).

4）地球温暖化対策推進本部, 京都議定書目標達成計画の進 渉状況 (2005).

5）地球温暖化対策推進本部, 京都議定書目標達成計画 (2006).

6）地球環境産業技術研究機構(編), $\mathrm{CO}_{2}$ 貯留テクノロ ジー, 工業調査会 (2006).

7）山地賢治，エネルギー・環境・経済システム論，岩波 書店 (2006).

8）UNFCCC，気候変動枠組条約，国際連合 (1992). 